\begin{tabular}{|l|l|l|}
\hline \multicolumn{2}{|c|}{ PublisherInfo } \\
\hline \hline PublisherName & $:$ & BioMed Central \\
\hline \hline PublisherLocation & $:$ & London \\
\hline \hline PublisherImprintName & $:$ & BioMed Central \\
\hline \hline
\end{tabular}

\title{
Lining-up Listeria genomes
}

\begin{tabular}{|l|l|l||}
\hline \multicolumn{2}{|c|}{ ArticleInfo } \\
\hline \hline ArticleID & $:$ & 4236 \\
\hline \hline ArticleDOI & $:$ & $10.1186 /$ gb-spotlight-20011026-01 \\
\hline \hline ArticleCitationID & $:$ & spotlight-20011026-01 \\
\hline \hline ArticleSequenceNumber & $:$ & 307 \\
\hline \hline ArticleCategory & $:$ & Research news \\
\hline \hline ArticleFirstPage & $:$ & 1 \\
\hline \hline ArticleLastPage & $:$ & 2 \\
\hline \hline & $:$ & RegistrationDate : 2001-10-26 \\
ArticleHistory & $:$ & OnlineDate $\quad$ 2001-10-26 \\
\hline \hline ArticleCopyright & $:$ & BioMed Central Ltd2001 \\
\hline \hline ArticleGrants & $:$ & \\
\hline \hline ArticleContext & $:$ & 130592211 \\
\hline \hline
\end{tabular}




\section{Jonathan B Weitzman}

Email: jonathanweitzman@hotmail.com

Listeriosis is caused by the ingestion of pathogenic Listeria monocytogenes in contaminated food. In the October 26 Science, Glaser et al. report a comparative analysis of Listeria genomes aimed at identifying virulence genes (Science 2001, 294:849-852). They sequenced the genomes of two Listeria strains; pathogenic L. monocytogenes EGD-e and a non-virulent species L. innocua. L. monocytogenes contains a single circular chromosome of $2.9 \mathrm{Mb}$, while $L$. innocua has a $3 \mathrm{Mb}$ chromosome and an 80 $\mathrm{kb}$ plasmid. The two genomes encode similar numbers of genes: almost 3000 open reading frames, of which a third code for proteins with no known, or predicted, function. The two genomes encode large numbers of putative surface proteins, transport proteins and transcriptional regulators. Many of these are likely to account for virulence and for the adaptability of Listeria species to diverse environmental conditions. Glaser et al. identified hundreds of strain-specific genes, which are clustered in islets. They conclude that their study "opens new avenues for post-genomic analysis of the life-styles of $L$. monocytogenes in the environment and the infected host."

\section{References}

1. Listeria pathogenesis and molecular virulence determinants.

2. Science, [http://www.sciencemag.org] 